\title{
ASPECTE ALE SACRULUI ÎN TOPONIMIA MINIERĂ Din Roșia Montană și BuCiUM
}

\author{
Cosmina-Maria Berindei \\ Academia Română - Filiala Cluj-Napoca \\ Institutul de Lingvistică și Istorie Literară „Sextil Pușcariu“, România
}

\section{Sacred aspects in mining-related toponyms of Roşia Montană and Bucium}

\begin{abstract}
Our paper proposes an analysis of hagiographic mining toponymy in two villages located in the Western Carpathians, from the perspective of the sacred. Data were collected from a study on mining toponymy and validated during fieldwork. Research findings indicate that mining toponymy is closely related to the specificity of mining work, beliefs, hopes and sufferings. Most hagiographic toponyms refer to martyrs, known for their endurance. Two toponyms refer to Saint Nepomuk, the keeper of mysteries. Others are correlated with honesty. In conclusion, we show that hagiographic mining toponymy reflects the experience of the sacred in the life of the community.
\end{abstract}

Keywords: toponymy, hagiography, mining, sacred, beliefs.

Lucrarea de față își propune o analiză din perspectiva sacrului a toponimiei miniere din două localități învecinate situate în Munții Apuseni, având acces la același masiv aurifer: Roșia Montană și Bucium. Am supus observației toponimele cu rezonanță hagiografică prin care erau numite galerii miniere sau filoane de zăcământ aurifer aflate în arealul celor două localități.

Lucrarea noastră face parte dintr-un demers de cercetare mai amplu, care a vizat identificarea aspectelor ce definesc identitatea ocupațională a mineritului aurifer în Munții Apuseni. De această dată ne-am propus să observăm în ce măsură toponimia minieră din registrul hagiografic reflectă reperele mitologice miniere și sunt expresie a credințelor articulate în aceste comunități.

Așa cum sublinia Mircea Eliade, orice regiune locuită, configurată ca un microcosmos, posedă un centru, adică un loc sacru prin excelență, datorită importanței pe care o are în viața celor care-o locuiesc (v. Eliade 1994: 48). Centrul comunitățilorminiere este strâns legat de sursa existenței lor și se afla în adâncul pământului, de-a lungul filoanelor ascunse și nebănuite, stăpânite de ființe când binevoitoare, când potrivnice, care pot fi îmblânzite prin comportamente adecvate.

Este cunoscut faptul că sfinții venerați ca patroni ai unor spații sau ai unor categorii profesionale sau sociale erau protectori ai acestora, având rol apotropaic. Mineritul tradițional, ca și cel modern, era o activitate dificilă și periculoasă. Productivitatea în 
practicarea mineritului cu mijloace tradiționale era legată de noroc, iar speranța venea din protecția divină. Toată activitatea cotidiană, toate speranțele și temerile, dar și toate bucuriile și suferințeledin comunitățile de mineri erau strict legate de activitatea din mină. Valorificând aurul, minerii își obțineau cele necesare traiului, descoperirea unui filon bogat le putea schimba, în orice moment, definitiv, modul de viață. Este cunoscută istoria lui Mihăilă Gritta, minerul care, după ce a descoperit 1770 de kilograme de aur a construit șapte biserici și șapte școli în localitățile din împrejurimile Roșiei Montane, unde își avea minele. Cercetarea pe care am efectuat-o pe teren, la Roșia Montană și la Bucium între anii 2007-2013, ne-a reliefat valoarea „sacramentală” - în termenii lui Mircea Eliade - pe care comunitatea o acordă resursei miniere. Cercetarea a fost efectuată într-o perioadă de criză pentru comunitate, generată de tensiunile apărute din cauza unui megaproiect industrial, bazat pe cianurare, propus pentru exploatarea resursei miniere de către o firmă româno-canadiană. Momentul de criză i-a determinat pe locuitori să reflecteze mai profund la ceea ce a însemnat resursa auriferă pentru familiile lor, pentru comunitatea lor, pentru întreaga zonă.

Pentru a înțelege mai bine observațiile pe care le vom face în legătură cu toponimia minieră, este necesar să ne oprim asupra istoriei practicării mineritului tradițional în aceste localități din Munții Apuseni, configurate în jurul Abrudului, uneori subordonate administrativ acestui oraș, alteori, de-a lungul secolelor, având administraţii proprii. În această zonă a funcționat un centru minier încă din perioada preromană. Roșia Montană, cunoscută sub numele de Alburnus Maior, a fost atestată documentar la 6 februarie 131 p. Chr., printr-un document juridic scris pe o tăbliță cerată care-a fost descoperită într-o galerie minieră romană. Atât la Roșia Montană, cât și la Bucium, vestigiile arheologice, însemnările de diferite feluri și istoria orală ne oferă mărturii ale exploatării aurului folosind instalații artizanale până la 11 iunie 1948 când, prin Legea nr. 119 pentru naționalizarea întreprinderilor industriale, bancare, de asigurări, miniere și de transporturi, mineritul tradițional a fost oprit de către puterea comunistă, minele au fost naționalizate și s-a deschis o exploatare minieră industrială, la suprafață, în Roșia Montană, care a adunat apoi întreaga forță de muncă din zonă. Închiderea minelor la momentul naționalizării a fost o experiență traumatizantă pentru întreaga comunitate, oamenii fiind nevoiți să se orienteze înspre alte surse de trai. Pe de altă parte, zidirea gurilor de mină, prin care se limita accesul la resursa auriferă, a scăzut importanța lor pentru viața cotidiană. Ele au încetat să mai constituie puncte de reper spațial și, cu timpul, au fost efectiv uitate. Persoanele care cândva au avut experiența lucrului în mină își mai aminteau numele pe care comunitatea le dădea galeriilor miniere. Oamenii mai tineri nu mai cunosc denumirea galeriilor miniere. Faptul că ele au încetat să mai fie folosite ca puncte de reper spațial în discuțiile cotidiene este și un rezultat al persecuțiilor îndreptate împotriva minerilor pentru a preda aurul după naționalizare. Discreția totală în legătură cu orice fapt care ducea cu gândul la aur era cea mai înțeleaptă decizie pentru a nu stârni niciun fel de suspiciuni. În acest fel, toponimia minieră, un capitol important al moștenirii culturale în comunitățile miniere, a fost uitată.

Toți cei care mai știu informații vagi despre toponimia minieră sunt astăzi 
persoane foarte vârstnice. De la 1948 s-au scurs aproape șaptezeci de ani, iar cei care-au lucrat în mină sunt oameni trecuți de nouăzeci de ani și din ce în ce mai puțini.În ceea ce privește metodologia de cercetare, precizăm că în etapa de informare și colectare a datelor în vederea realizării acestui studiu am efectuat cercetări de teren directe, dar am apelat deopotrivă la studiul Toponime din bazinul Abrudului referitor la minerit, publicat în 1997 de către Emil Popa, profesor de limba și literatura română la liceul din Abrud (Popa 1997: 193-221). Autorul studiului a avut în vedere înregistrarea toponimelor conform următoarelor trei categorii: numele de mine și alte locuri de la suprafață care fac referire la galerii miniere, nume din subteran și nume care se referă la activitatea de prelucrare a minereului (Popa 1997: 194). Pentru a colecta datele toponimice, Emil Popa a apelat la persoane vârstnice care avuseseră experiența exploatării aurului direct din galerii, al căror număr era mult mai mare în anii în care a desfăşurat cercetarea decât al celor care ne-au putut servi nouă, la o distanță de cel puțin douăzeci de ani după aceea, drept informatori. Chiar dacă a colectat datele într-o perioadă în care încă existau persoane care au lucrat în mineritul tradiţional, Emil Popa a întâmpinat dificultăți în cercetare din cauză că , au fost uitate numeroase nume din interiorul minelor, ca urmare a părăsirii lor și a sistării mineritului individual" (Popa 1997: 194). Studiul realizat de profesorul din Abrud constituie astăzi un document foarte prețios, întrucât reconstituirea cartografică/toponimică se dovedește deosebit de dificil de realizat. Am încercat la început un astfel de demers care s-a dovedit imposibil. De aceea, în etapa a doua a cercetării, am folosit un ghid de interviu, prin care am orientat discuția înspre verificarea, pe baza memoriei interlocutorilor, a existenței minelor care poartă nume de sfinți pe care le excerptasem din studiul amintit. În cele mai multe cazuri informatorii au confirmat c-au auzit de mina cu numele respectiv, dar că nu știu concret unde este situată aceasta.

În etapa de interpretare a datelor am folosit informaţii colectate personal în timpul campaniilor de cercetare de teren, efectuate în perioada 2007-2013, cu metode specifice cercetării sociale calitative: interviul structurat și semistructurat și interviul de tip povestea vieții. De asemenea, importante în demersul de analiză a datelor ne-au fost legendele și povestirile miniere publicate de Maria Botiș-Ciobanu, Maria Ioniță, Ana Şoit și Norberth Fisch, dar și o serie de studii etnografice.

Din punct de vedere cantitativ am identificat un număr de douăzeci și șapte de mine care poartă numele a douăzeci și unu de sfinți, întrucât în sate diferite ale celor două comune au fost identificate mine care poartă același nume.

Redăm în continuare, în ordine alfabetică, lista toponimelor miniere cu caracter hagiografic:

Baia Arhanghelii (Bucium Poieni)

Baia Barbara (<Varvara) (Bucium Izbita, Bucium Sat, Roșia Montană)

Baia Cătălina (Roșia Montană)

Baia Maria Magdalena (Bucium Izbita)

Baia la Nepomuc (Bucium Poieni) 


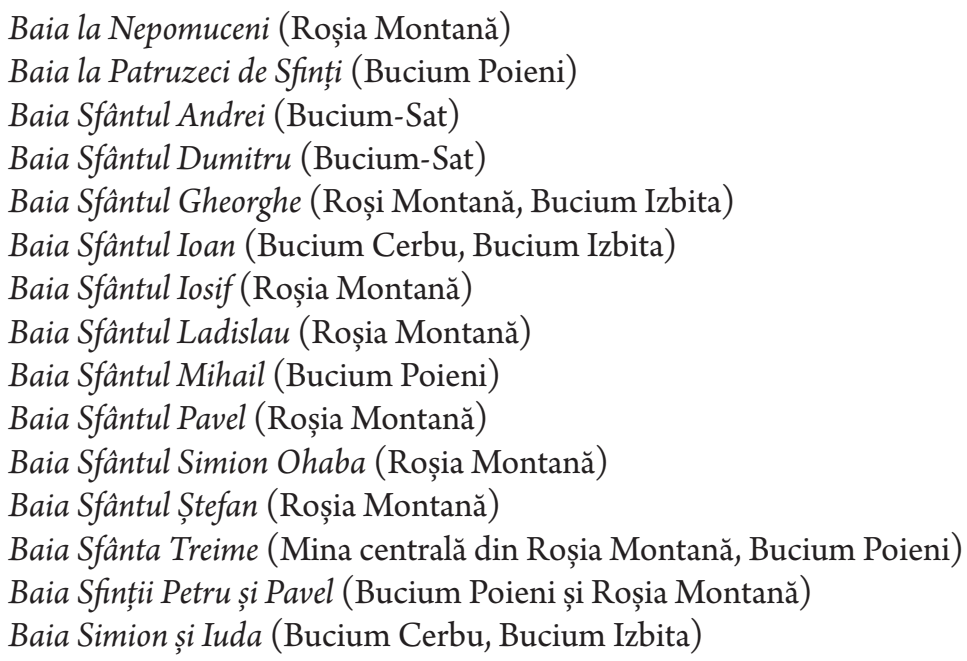

Baia Barbara (<Varvara) este numele dat pentru a denomina galerii miniere în trei sate din cele două localități: Bucium Izbita, Bucium Sat, Roșia Montană, iar Baia Sfântul Gheorghe, Baia Sfântul Ioan, Baia Sfinții Petru și Pavel, Baia Simion și Iuda, Baia Sfânta Treime cunosc, fiecare, câte două ocurențe în toponimia zonei.

În continuare vom încerca să arătăm care sunt atributele sfinților ale căror nume apar în toponimia minieră din Roșia Montană și Bucium și în ce măsură acestea reflectă nevoia de protecție sau de sprijin ce-ar putea reveni de la sfântul respectiv, având în vedere specificul activităților miniere.

Sfânta Barbara (<Varvara), cunoscută ca patroană a minerilor și a geologilor este o sfântă martiră a creștinismului. Perseverența sa în credință l-a determinat pe tatăl ei s-o omoare. Sfânta Ecaterina (<Cătălina) are, de asemenea, atributul perseverenței. Descendentă dintr-o familie nobilă, de o frumusețe și de o înțelepciune aparte, a refuzat să se căsătorească fiindcă nu și-a găsit un soț pe măsură. S-adedicat întru totul credinței creștine și, din acest motiv, a fost omorâtă la ordinul tatălui său. Un alt sfânt a cărui nume se regăsește în toponimia minieră și al cărui atribut este perseverența este Sfântul Simion. De altfel, toți sfinții martiri ale căror nume sunt preluate de toponimia minieră se caracterizează prin perseverență, o calitate pe care minerii trebuia s-o aibă pentru a reuși să ajungă la filoanele de aur.

În interviurile de tip povestea vieții pe care le-am realizat cu fiii unor foști proprietari de mină sau mineri, deseori aceștia au accentuat aspectul perseverenței și al răbdării de care minerii trebuiau să dea dovadă în lupta cu piatra. Răbdarea era importantă mai ales atunci când se deschidea o mină. Până se ajungea la filon, adică la minereul bogat în aur, uneori proprietarii își investeau toate resursele:

Și atâta ne-o purtat de rău când am fost mici! Că în continuu construia și acolo o băgat banii, tot să facă mai mult.(...) Trebuie să lucreze mult până dădeau aur. Că, cine nu 
cunoaște filonul... că îi mai subțire ca firul de păr. Poți merge până-n București, că nu-l găsești, dacă nu-l cunoști. Și-aci, cine cunoaște aurul trebuie să fie ca un doctor, cum cunoaște un doctor organismul și venele-n om. Așa-i și aurul. Nu se găsește așa, că mă bag în mină și cum dau cu ciocanul găsesc. Vai, Doamne ferește! Și vă dați seama... ${ }^{1}$

Astfel de observații sunt păstrate și în legendele și povestirile minerești: „Baia asta a fost ca tăte băile și bună și ra. Bună când dădeai de aur și ra când nu scoteai nici banii de cheltuială pe țindăr. Da noi credeam în noroc și munceam cu speranța că da de, da de...” (Șoit 1974: 3-4).

Baia la Patruzeci de Sfinți trimite, de asemenea, la sfinții martiri. Este vorba despre cei patruzeci de mucenici despre care se spune că au suferit martiriul, fiind răsplătiți pentru perseverența lor de a rezista în apa înghețată în care erau torturați pentru a trece la păgânism. Alături, un lac cu apă caldă îi ispitea să-și lepede credința. Unul dintre ei, nemaiputând îndura chinul gerului a încercat să treacă în celălalt lac, dar a murit pe drum. Dumnezeu, s-a îndurat atunci și a încălzit apa în care stăteau, iar pentru perseverență i-a răsplătit așezând cununi strălucitoare pe capetele lor, spre mirarea paznicilor.

Ceea ce leagă atributele acestor sfinți de activitatea minieră este legătura sărbătoririi lor, în 9 Martie, de revenirea primăverii, când apa se dezgheață. Mineritul fiind legat de sursa de apă, dezghețarea râului care trece prin localitate aducea binefacere minerilor care, de obicei, odată cu această sărbătoare, puteau să pornească instalațiile artizanale pentru a alege aurul.

Baia Sfântul Iosif, Baia Sfântul Mihail, Baia Arhanghelii sunt alte toponime care au caracter hagiografic. Sfinții ale căror nume le poartă sunt garanți ai dreptății. Sfântul Iosif este cunoscut și sub numele de Dreptul Iosif, om onest, cu o credință neclintită. Arhanghelii Mihail și Gavrilau conotație escatologică. Ei sunt prezenți în momentul Morții, Mihail este considerat în imaginarul creștin scribul justițiar al lui Dumnezeu, cel care ține socoteala faptelor bune ale oamenilor (Kernbach 1995: 211). Mihail este prezent și în momentul judecății sufletului, stând lângă balanța dreptății. Gavril are, de asemenea, un rol escatologic. El este îngerul păzitor al sufletelor.

Onestitatea era, pe lângă perseverență, o calitate pe care minerii trebuiau s-o dovedească pentru a avea noroc să găsească de aur, în primul rând, și să se bucure de banii obținuți, în al doilea rând. În imaginarul comunităților miniere, Vâlva Băii are un rol asemănător celui pe care îl au sfinții justițiari, cu deosebirea că acest rol se referă la existența cotidiană terestră, nu la o posibilă răsplată în Lumea de Dincolo. Vâlva Băii probează continuu onestitatea minerului. Acest personaj mitologic are caracteristicile unui judecător tainic al minerilor, supunându-i neîncetat unor probe, ajutându-i pe cei onești și pedepsindu-i pe cei nedrepți. O legendă excerptată din colecția publicată de Maria Ioniță este elocventă în acest sens:

1 Informație de teren. Interlocutoare: J. M., 82 de ani, din Roșia Montană. Interviu de tip povestea vieții realizat la Roșia Montană, în data de 1 aprilie 2012. 
Era odată un om sărac. Când a mers supărat în baie, i-a ieșit Vâlva Băii îmbrăcată în alb şi i-a zis ca să nu mai fie supărat că îl duce într-un loc bun. L-a dus într-un loc necunoscut unde era mult aur și i-a zis să ia aur cât poate să ducă la bancă. I-a mai spus că să-l vândă și apoi să vină să împartă banii.

Omul a luat aur cât a putut duce, l-a vândut și a împărțit banii în două. Oricum a făcut, un ban nu-l putea nicicum împărți în două. Atunci el s-o gîndit că mai bine să-l ducă la Vîlva Băii.

Vîlva Băii l-a întîmpinat sub formă de bătrîn şi l-a dus în alt loc, într-o galerie necunoscută ce avea la mijloc un vîrtej peste care era o punte. La capătul punții l-a pus să numere banii. Cînd i-a spus omul că leul care era în plus l-a adus cu el, Vîlva i-a zis:

- Dacă nu-mi aduceai leul și nu împărțeai pe dreptate, te aruncam în vîrtej, dar așa, că ai fost cinstit, fie și banii ăștia ai tăi (Ioniță 1982: 52-53).

O altă legendă vorbește despre felul în care Vâlva i-a pedepsit pe unii proprietari de mină, care nu și-au ținut cuvântul:

Odată or avut vorbe cu un băieș. Nu i-or plătit cum o fost înțelesul. Și băieșul o blăstămat: 'Cîte boabe de aur ați găsit, atâtea lacrimi să vă ardă ochii.'

Și mare năpastă s-o abătut pe toată familia lor, blăstăm curat, ca al băieșului. Praf s-o ales de ei. Unii spun că băieșul acela ar fi fost vîlva care i-o cercat când or fost mai bogați. De-atunci nime nu l-o mai văzut. Din tătă bogăția n-o rămas nimic. Și unde stătea odată aurul cât boaba, nu-i decât stărp.

Cînd te cearcă vîlvele nu-ți trăbă alt năcaz, asta o știe orice băieș (Șoit 1974: 18).

Sfinții justițiari ai căror nume se regăsesc în toponimia minieră amintesc necontenit minerilor că trebuie să fie onești, deoarece în lumea de dincolo vor avea de trecut probele Judecății de Apoi, iar faptele rele îi vor determina să ajungă în iad. În aceeași categorie intră Petru și Pavel, iar Sfântul Gheorghe, ucigătorul balaurului este un triumfător în lupta cu forțele malefice.

Baia Maria Magdalenaeste numită astfel după personajul biblic ce a descoperit minunea Învierii lui Iisus. Pentru miner, fiecare intrare în mină putea însemna descoperirea unei minuni. Numele dat acesteia este expresie a speranței.

Toponimele care se referă la Sfântul Ioan Nepomuk sunt, înainte de toate, expresia multiculturalismului ce caracterizează zona minieră din Munții Apuseni. Nepomuk a fost un preot și un martir creștin de origine germană din Boemia, care a trăit în secolul al XIV-lea. El a respectat taina sacramentului și nu a divulgat regelui păcatele săvârșite de soția sa, în ciuda faptului că și-a pierdut viața. De aceea a devenit protector al celor care păstrează o taină. În toponimia regiunii pe care am cercetat-o există două mine care poartă numele sfântului: Baia la Nepomuk și Baia la Nepomuceni, cea din urmă denumită după numele unei asociații de mineri care-l avea drept patron pe Sfântul Ioan Nepomuk. În viața comunităților de mineri din cele două localități păstrarea secretului avea o încărcătură sacră. Întrucât holongăritul, adică furtul minereului direct din galeria minieră nu era considerat un păcat și nu era pedepsit, considerându-se că resursa auriferă este darul lui Dumnezeu la care poate avea acces oricine, secretula devenit un fel de 
instituție socială. Legendele despre Vâlva Băii au articulat instituția secretului. Unele dintre ele vorbesc despre faptul că, după ce Vâlva îi arată minerului locul unde urma să găsească aur, îi cerea acestuia să nu spună nimănui, până în momentul morții. Dacă secretul nu era păstrat minerul era pedepsit:

La baia de lângă Tăul Brazilor băiau șase ortaci. Într-o duminică, unul s-o dus să vadă nu s-or băgat holoangării să ducă piatra. În baie i-a ieșit vâlva și l-a întrebat:

- Ai venit să lucri?

- Nu.

- Da aur îți trăbă?

- Da, o zâs băieșul înghețat de frică și bucuros.

Vâlva l-o chemat să meargă cu ea și cum mergea așa se deschidea întregul, până au ajuns într-o corandă mare. Cât o văzut cu ochii, numai aur dărăbuțe. Atunci vâlva i-o zâs să încarce cât poate duce el.

'Da faci legământ să nu spui ce-ai văzut și să nu mai pui piciorul pe baie.'

Băieșul o făcut legământul și-o cărat aurul acasă. La vreo 2-3 zile or vinit ortacii la el și l-or întrebat că-i bolnav de nu merge la lucru. 'Nu-s bolnav, dar nu mă mai duc pă baie. Și nici n-am pretenție să-mi dați din ce-am lucrat cu voi.'

Trecând vreo 5-6 ani, la un pahar, s-o scăpat și o spus și în momentul acela o paralizat de la brâu în jos. Și-o călcat legământul făcut vâlvei. Și ele nu iartă niciodată (Șoit 1974: 16).

Alte legende amintesc despre secretulpe care Vâlva Băii îl destăinuie unui miner, iar acesta îl păstrează inclusiv față de familie,divulgându-l doar pe patul de moarte. Așa este legenda despre Vuzdugan Francisc care lucra la Baie la Cătălina, iar la un moment dat vâlva îi arată aur cu care își umple desagii. Plecând, îi cere să nu spună nimănui unde-a găsit aurul, fiindcă va merge acasă și-l va omorî. Ajuns pe patul de moarte, la 86 de ani, acesta socotește că oricum va muri și le spune nepoților taina păstrată mult timp. În acea noapte vâlva a mers la el acasă și l-a omorât. Nepoții n-au mai găsit aur la locul indicat, ei neavând atâta credință (Șoit 1974: 18).

Într-o comunitate în care păstrarea secretului era atât de important, este ușor de înțeles motivul pentru care numele sfântului protector al celor care păstrează taina a fost preluat în toponimia minieră.

Toponimia minieră cu rezonanță hagiografică reflectă experiența sacrului în viața comunității, implicând noțiunile de „ființă, semnificație și adevăr” (Eliade 2000: 11). Având experiența muncii într-un spațiu în care viața le era mereu pusă în pericol, minerii au articulat un imaginar prin care sacrul mediază relaționarea cu lumea exterioară. „Prin experiența sacrului, spiritul uman a sesizat diferența între ceea ce se revelă ca fiind real, puternic, bogat și semnificativ și ceea ce este lipsit de aceste calități, adică curgerea haotică și periculoasă a lucrurilor, aparițiile și disparițiile lor fortuite și vide de sens” (Eliade 1969: 7). Astfel, sfinții din hagiografia creștină care au intrat în toponimia minieră au atributele prin care sunt exprimate experiențele lor cotidiene: perseverența, dreptatea, păstrarea tainei, umilința. 


\section{Referințe bibliografice}

Atkinson, R. 1998. The Life Story Interview. Thousand Oaks: Sage University Papers Series.

Butură. V. 1969. Spălarea aurului din aluviuni și mineritul țărănesc din Munții Apuseni. Anuarul Muzeului Etnografic al Transilvaniei. 1965-1967: p. 25-93.

Cuceu, I. 1999. Fenomenul povestitului. Cluj-Napoca: Editura Fundației pentru Studii Europene. Eliade, M. 1969. La nostalgie des origines: Méthodologie et histoire des religions. Paris: Gallimar.

Eliade, M. 1994. Imagini și simboluri.Eseu despre simbolismul mitico-religios. București: Humanitas. Eliade, M. 2000. Istoria credințelor şi ideilor religioase. Bucureşti: Univers Enciclopedic.

Fisch, N. 2010. Legende și povestiri din Munții Apuseni. Cluj-Napoca: Tradiții Clujene.

Geertz, C. 1973. The Interpretation of Culture. New York: Basic Books.

Hedeșan, O. 2000. Pentru o mitologie difuză. Timișoara: Marineasa.

Ioniță, M. 1982. Cartea Vîlvelor. Legende din Apuseni. Cluj-Napoca: Dacia.

Kernbach, V. 1995. Dicționar de mitologie generală. Mituri. Divinități. Religii. Bucureşti: Albatros. Popa, E. 1997. Toponime din Bazinul Abrudului referitoare la minerit. In Țara Moților. Studii, articole și comunicări: Vol. V, Nicolae Mocanu și Nicolae Edroiu (eds.), 193-221. Cluj: Clusium. Șoit, A. 1971. Legende populare minerești. București: Minerva. 